Insight, part of a Special Feature on A brave new world: integrating human well-being in conservation

\title{
Moving beyond the human-nature dichotomy through biocultural approaches: including ecological well-being in resilience indicators
}

\author{
$\underline{\text { Sophie Caillon }}^{1}, \underline{\text { Georgina Cullman }}^{2,3}, \underline{\text { Bas Verschuuren }}^{4}$ and Eleanor J. Sterling $^{2}$
}

\begin{abstract}
Diverse and productive ecosystems and human well-being are too often considered opposing targets. This stems mainly from nature being perceived as separate from culture, which results in resilience indicators that focus predominantly on either ecosystems or humans, and that overlook the interplay between the two. Meanwhile, global targets for biodiversity conservation and human wellbeing have yet to be satisfactorily achieved. We believe that in order to develop effective, culturally appropriate, and equitable conservation strategies that ensure social-ecological resilience, conservation planners and practitioners must conceive of human and ecological wellbeings as an interrelated system. By giving nature a voice, and by viewing nature and people as an undifferentiated whole, some indigenous peoples and local communities (IPLC) have philosophical bases for achieving well-being for both humans and nature. Biocultural approaches to conservation ground management in local knowledges, practices, and ontologies. These approaches encompass both the biological and cultural aspects of a system, address complex relationships and feedbacks within human and ecological well-being, and offer flexible frameworks that facilitate synthesis across different metrics, knowledge systems, and ontologies. The process of developing indicators of resilience with a biocultural approach could help (1) overcome the human-nature dichotomy that often makes global approaches incompatible with local approaches by integrating local peoples' diverse forms of relating to nature, (2) reflect two-way feedbacks between people and their environment by focusing on processes, not just final states, and (3) define, measure, and monitor ecological and human well-being as a whole. It can also facilitate dialog between IPLCs and global decisionmakers who are disconnected from local realities, and between people from a diversity of disciplinary, ontological, and professional backgrounds.
\end{abstract}

Key Words: biocultural approach; conservation; ecological well-being; human well-being; indicator; indigenous peoples and local communities; nature-culture; ontology; resilience; traditional ecological knowledge

\section{INTRODUCTION}

Despite growing awareness and efforts to conserve biodiversity, ecosystems worldwide are still declining (Botsford et al. 1997, Vitousek et al. 1997, Butchart et al. 2010, Newbold et al. 2016) while people still struggle to lead a life in which they themselves can decide how to improve their well-being (UNDP 2016). Policymakers and scientists too often frame the targets of diverse and productive ecosystems and healthy human societies as if they were in opposition (Raudsepp-Hearne et al. 2010, McShane 2011). This framing shapes the development of indicators for managing biodiversity and human well-being. Most internationally derived indicator sets (e.g., GDP ranking, world development indicators, IUCN Red List index) measure ecosystem and human health separately. Recent efforts to reconcile nature conservation and human development include promoting the integration of social sciences into conservation (Mascia et al. 2003, Agrawal and Ostrom 2006, Brosius 2006, Peterson et al. 2010, Barry and Born 2013, Sandbrook et al. 2013, Bennett et al. 2016, Ives et al. 2017) and the integration of local actors (e.g., community members, NGOs, local government) into research and action through social-ecological systems resilience studies, community-based management, or in situ conservation of agrobiodiversity (Altieri and Merrick 1987, Alcorn 1993, Pinedo-Vásquez and Padoch 1993, Berkes 2008, Liu and Opdam 2014, Ens et al. 2016). These efforts have led to (1) more nuanced human well-being indicators, modified from the Human Development Index, to better integrate material conditions, quality of life (e.g., spiritual dimensions, social connections, environmental quality, and subjective well- being), and sustainability of well-being (i.e., human, social, economic, and natural capital) (Clark 2014, OECD 2015, Biedenweg et al. 2017, Gross-Camp 2017, Wali et al. 2017), and (2) sets of indicators, such as the United Nations Sustainable Development Goals, that include people-focused and ecological goals but fall short in integrating these domains through attention to the feedbacks and interactions between humans and the environment.

Defining, measuring, and monitoring biodiversity and human well-being indicators separately may result in irrelevant or disruptive actions on the local scale (Jupiter 2017, Sterling et al. $2017 b$ ). We advocate for comparable investment in indicators that integrate the specific well-being of ecosystems and the relationship between humans and nature that maintain these wellbeings. Equitable conservation strategies can be achieved only if we believe in a joint future for ecological and human well-beings by (1) actively engaging with the diversity of knowledges, practices, and ontologies (i.e., different realities with complex relations between distinct categories of being; for example, between humans and nonhumans, such as landforms, spirits, rocks, trees, energy), (2) moving beyond the dichotomy between people and nature, and (3) giving nature a voice.

We are aware that ecological well-being is difficult if not impossible to define generically, but when grounded in a place and in relation to the peoples who manage that place, it is possible to articulate preferred states as well as specific notions of respect, caring, and responsibility for nature that are held by a given social

${ }^{1}$ CEFE UMR 5175, CNRS - Université de Montpellier - Université Paul-Valéry Montpellier - EPHE - IRD, France, ${ }^{2}$ Center for Biodiversity and Conservation, American Museum of Natural History, USA, ${ }^{3}$ Forestry, Horticulture, and Natural Resources, New York City Department of Parks \& Recreation, USA, ${ }^{4}$ Department of Sociology of Development and Change, Wageningen University, Netherlands

Erratum: The authors' affiliations given in the original publication of this paper were incorrect. Corrections were made on 28 November 2017. 
group. We have much to learn from other knowledge traditions (Matulis and Moyer 2016), in particular, the importance of relational values (Chan et al. 2016, Pascual et al. 2017) that apply to interactions with place (i.e., the concepts of place attachment or sense of place) (cf. Massey 1991, Ingold 2000, Poe et al. 2016). Moving beyond the human-nature dichotomy in conservation practices results in a different relationship and hierarchy between humans and nature, and a contingent responsibility on the part of humans to nurture the environment and not just benefit from it (Pascual et al. 2017).

Ignoring the feedbacks and interactions between humans and ecosystems is ahistorical, a denial of the often generations-long relationships between people and their environments. It ignores omnipresent human influence on ecosystems and people's rights to their territories and resources (Gillson and Willis 2004, Heckenberger et al. 2007, van Oudenhoven et al. 2011). In addition, framing conservation objectives in terms of "reverting" to a prior, pristine nature, as is often implied in conservation and restoration strategies, both impedes us from imagining transformative futures and recreates the structural elements that have resulted in present-day environmental degradation and cultural erasure (West 2016). Here, we use the term "nature" when noting human perceptions and conceptual interactions with the environment. We use the more technical term "ecosystem" when presenting scientific realities such as "ecosystems are dynamic" or when discussing human management or use of the material component of the environment. Both terms encompass the processes and interactions that support systems, not just isolated individuals. For culture, we have adopted Bates and Plog's definition (1990:7) "the system of shared beliefs, values, customs, behaviors, and artifacts that the members of society use to cope with their world and with one another, and that are transmitted from generation to generation," and within the same generation through learning. Thus, culture is holistic, dynamic, ubiquitous, and learned.

We explore the implications of including paired ecological and human well-being in conservation practices through biocultural approaches - ones that include the dynamic interactions between local knowledges, practices, and ontologies, and recognize the generative interrelationships between people and their environment, and the processes and feedbacks that sustain ecological and human well-being (Maffi and Woodley 2010, Gavin et al. 2015, Sterling et al. 2017b, McCarter et al. 2018). Biocultural approaches are gaining traction in resource management arenas and particularly with international conventions and platforms (e.g., Convention on Biological Diversity, Intergovernmental Science-Policy Platform on Biodiversity and Ecosystem Services [IPBES], United Nations) (Gavin et al.2015, Pascual et al. 2017, Sterling et al. 2017b). Taking into account the mutualistic relation between local peoples, particularly indigenous peoples and local communities (IPLCs), and the environment (Kuznar 2001, Cairns 2007) does not exclude scientific measurements and monitoring of ecosystem states, processes, interactions, and functions. Local knowledges and western sciences, especially the discipline of community ecology, share common concepts such as connectedness and relatedness (Pioretti and Wildcat 2000), aspects specifically recognized as a core concern to conservation (Zylstra et al. 2014). Western sciences have supported objectives defined by local peoples (Bartlett et al. 2012, Muller 2012, Verschuuren et al. 2015).
The creation and measurement of resilience indicators (capturing the capacity of systems to absorb shocks and disturbances, and to catalyze renewal, adaptation, transformation, and innovation) (cf. Béné et al. 2013) through a biocultural approach can contribute to equitable conservation strategies that achieve wellbeing for humans and nature. Biocultural approaches recognize and emphasize IPLCs' realities through an emic approach, which aims to illuminate IPLCs' own understandings of their relationships to nature (as opposed to a priori theoretical frameworks that underpin etic approaches). The approaches take into account interactions between humans and nature, and try to integrate connections - including both convergences and divergences - between local and scientific knowledges. The coconstruction of indicators of resilience can also facilitate dialog between IPLCs dwelling with nature and other decision-makers, and between people from a diversity of backgrounds (Verschuuren et al. 2014). A focus on the interactions between people and their environment facilitates attention to processes in addition to final states. We propose that conservation planning and policy should address the diversity of knowledges (including classification systems) and practices embedded in different ontologies. Additionally, given human embeddedness within ecosystems, ecological well-being in and of itself should be considered by giving nature a voice. We believe that attention to how we measure and monitor progress toward targets can help bring these conceptual ideas into practice. The ideas in this paper reflect our experiences with peoples dwelling with nature, as well as discussions from workshops and organized sessions that convened diverse stakeholders (including scientists from different disciplines), backgrounds, and countries.

\section{A DIVERSITY OF LOCAL KNOWLEDGES, PRACTICES, AND ONTOLOGIES}

Humans in different places around the world make use of different ontologies that shape the worlds they know and see, and how they behave and interact with them. We define ontology as the conceptualization of the nature and relation of being. Ontologies are continuously in interaction with knowledges and practices, and through this interaction, distinct realities are enacted. This dynamic dialectic shapes a myriad of relationships to nature; materiality and immateriality are interconnected, indistinguishable, and produce one another. We are not describing how different groups of people have different perceptions of a single world (a multicultural etic approach), but rather are accepting the radical plurality of worlds, and thus of natures (a multinaturalist emic approach developed by Viveiros de Castro [1998]). Many IPLCs do not consider nature and humans as separate, and their views often differ from western-educated conservation agents (West 2006, Jupiter 2017). Since the 1980s, anthropologists such as Viveiros de Castro (1992), Strathern (1980), and Descola (1986, 2005) have documented such indigenous ontologies. They have described how small-scale societies conceive of themselves as part of their environment, and view their surroundings as kin. As reported by Descola (1986), the Achuar from the Ecuadorian Amazonian forest, for example, confer to nonhumans attributes that are similar to those of humans. Animals, according to the Achuar, have the same spirit, called wakan, as humans, and appear as animals only on the outside, as seen by others. Animals have a reflexive consciousness and intentionality; they can express emotions and communicate among themselves or with members of other species, like humans. 
Early anthropologists - including Durkheim and Mauss (1901), Evans-Pritchard (1940), Conklin (1954), and Levi-Strauss (1962) - as well as later ethnobotanists (Hunn 1977, Friedberg 1990, Berlin 1992, Ellen 1998) have shown the richness of local knowledges and practices in relation to nature by using IPLCs' lenses. For example, work on ethno-classifications shows that how people know and see the world is also how they classify it (Brown et al. 1976, Friedberg 1992). As such, each ontology results in different ways of seeing, ordering, ranking, and categorizing; this has profound implications for conceiving of problems, identifying solutions, and measuring success toward envisioned futures. The original goal of these early anthropologists and ethnobiologists was to understand societies through a society's own construct of knowledge on the environment, and not to understand the environment itself and its uses (Roué 2014). These ideas were the precursors of the biocultural approach we are promoting in this paper. More recently, "multi-species ethnography" looks to better integrate the strong and changing interconnections between humans and nature. It focuses on the multiple relations people have with their environment and how these relations make people become humans (Kohn 2007, Haraway 2008, Kirksey and Helmreich 2010, Ogden et al. 2013, Tsing 2015). This movement could bring new concepts and methods, and help improve mutualism between human and ecological well-being, especially if it also includes the study of the role of nonhumans.

Conservationists have noted that some aspects of local knowledges have strong parallels with western scientific categories and have aimed to use fragments of that knowledge - particularly those termed "ecological" knowledge - in service of conservation objectives (Gadgil et al. 1993, Huntington 2000, Berkes et al. 2000, Drew 2005, Menzies 2006, Aswani and Lauer 2014). However, local knowledges are dynamic, situational, and relational, and arise from a combination of common heritage and individual experience. They change and adapt in response to social and environmental changes. Knowledge about nature is entwined and built up with other types of knowledge - such as knowledge about death and ancestors, birth and children (West 2005). The different spheres or systems of knowledge developed by IPLCs are interconnected. Moreover, when trying to understand how local knowledges could contribute to conservation, the study of the processes and relationships that are mobilized to accumulate knowledge is often more informative than the end products, such as the number of plants known at the community level (Ellen 1998). It is important to understand how people transmit knowledge vertically (from parents to offspring), horizontally (among peers of the same generation), or obliquely (between lessrelated generations), thereby mobilizing their kin group, relatives, or external people.

New approaches developed in the context of IPBES emphasize using validation systems from within each knowledge system rather than using one knowledge system (for instance, western science) to validate information from another system (for instance, local knowledge) (Tengö et al. 2014). In part this is because definitions of human relationships to the environment based on different ontologies may conflict because they are not addressing the same system or perhaps the same reality. For example, Blaser (2009) describes how different ontologies and knowledges created conflict around the management of hunting in a park in Paraguay. In an agreement between the managers of the park and the Yshiro, the local indigenous people, sustainable hunting of anacondas (Eunectes notaeus) was explained to the Yshiro as hunting without impairing the hunt for future generations. The Yshiro thus set off to hunt a significant, but in their eyes sustainable, number of anacondas. The Yshiro believe in a culture of reciprocity, where the forest will continuously provide resources as long as relationships between all entities are in equilibrium. This involves communicating with "powers and potencies" of nonhuman entities, which is done through shamans. The conservation biologists did not agree with the resulting behaviors. Their own science-based strategy to achieve sustainability involves population viability of species calculated at a far lower uptake limit. Both parties were acting "correctly" with respect to their own understanding of sustainability. To reduce conflict, the Yshiro and the conservation biologists could have placed greater importance on the co-construction of indicators and operationalization of sustainable harvesting.

Conservation initiatives with IPLCs should work in partnership to apply knowledge from multiple knowledge systems and ontologies, and to better understand the reasons for different proposed strategies. Ignoring local ontologies by giving primacy to western framing of issues can exacerbate political, economic, religious, and educational inequalities, and ultimately frustrate conservation outcomes (Walley 2002, Atran et al. 2005, Bartlett et al. 2012, Verschuuren 2016). Creating channels toward a plurality of ontologies also means that biodiversity conservation strategies in territories of IPLCs cannot simply use conventional actions such as reducing "human pressure" (e.g., West 2005).

\section{NATURE SHOULD BE GIVEN A VOICE}

The scientific literature places a substantial emphasis on the positive impact of nature on human well-being, but only rarely the reverse (Biedenweg et al. 2014, Comberti et al. 2015). This lacuna can be explained in part by the fact that western ontologies do not give the same status to nature as to humans. In some other ontologies, rivers, trees, and rocks are animated and relate to people; nature is given a voice and acquires rights to existence, similar to humans (Emmenegger and Tschentscher 1994, Starik 1995, Cullinan 2002, Burdon 2011). Is this expansion of rights "unthinkable" beyond those cultures? No, there are parallels in western history when rights were afforded to groups previously denied similar status to other humans - e.g., slaves, women, and children (Stone 2010 [1972]).

Today, Ecuadorians have overcome the "unthinkable" with respect to nature's existence and rights. Ecuador's courts were the first to uphold the rights of nature. In the country's constitution of 2008, nature "has the right to exist, persist, maintain and regenerate its vital cycles, structure, functions and its processes in evolution" (Constitution of the Republic of Ecuador, Title II, Ch.7 "Rights of nature": Art.71). The court succeeded in asserting a harmony between people and nature (Becker 2011), thereby establishing a legal basis for the inherent rights of nature, and recognizing the indisputable importance of those rights in the present and for future generations (Daly 2012).

New Zealanders have acknowledged a former national park, Te Urewera, as "a legal entity" with "all the rights, powers, duties, and liabilities of a legal person" (Te Urewera Act 2014: section 11(1)). Te Urewera thus gained the status of an integrated, living whole with rights and interests according to the ontology of 
Tûhoe, a Mâori group. Mâori iwi are well-known for their close relationship with nature and their holistic ontology, called Kotahitanga, which recognizes how each individual's actions affects the collective (Marsden 1992, Mead 2003). Their relations with other humans and nonhumans is clear from the very start of the Act: Te Urewera is described as a "place of spiritual value, with its own mana and mauri" (section 3(2)), and his origin is storied as "Te Manawa o te Ika a Mâui; it is the heart of the great fish of Maui, its name being derived from Murakareke, the son of the ancestor Tûhoe.[...] Te Urewera expresses and gives meaning to Tûhoe culture, language, customs, and identity" (section 3(4,6)). (According to the Mâori dictionary [Moorfield 2011], mana means the "prestige, authority, control, power, influence, status, spiritual power, charisma-mana is a supernatural force in a person, place or object," and mauri means "life principle, life force, vital essence, special nature, a material symbol of a life principle, source of emotions - the essential quality and vitality of a being or entity. Also used for a physical object, individual, ecosystem or social group in which this essence is located"). The law empowers Tûhoe stewardship of Te Urewera and enables the continuation of this generative relationship between people and place.

Once a natural entity gains legal standing, what are the implications in terms of assessing obligations to it? Is it appropriate to conceive of ecological well-being or ecosystem "health," or should the scientific lexicon, such as ecosystem state/ biodiversity/processes/functions/resilience, continue to predominate? The ecosystem health literature (e.g., Schaeffer et al. 1988, Costanza et al. 1992) proposes measurement in terms of vigor, organization, and resilience (Costanza 2012), and is generally associated with a utilitarian value and western understandings of ecosystems. The term ecosystem health can be used without reference to feedbacks with people, though some authors do recognize these links (Tiwari et al. 1998, Spiegel et al. 2001, Tzoulas et al. 2007). We believe that using the same term "wellbeing" for humans as well as nonhumans helps reinforce interactions and processes between humans and nature. In addition, the use of well-being encourages a focus not just on the absence of physical illness or decline in ecosystem state, but also on less easily translated elements such as connection to place, or mental and spiritual well-being of nonhumans (West 2005).

Again, New Zealanders are pioneering. The Whanganui River is also granted legal personhood (i.e., a "legal entity with standing in its own right" (Tûtohu Whakatupua, Whanganui Iwi and the Crown (2012): section 2.1.2), and its well-being is highlighted repeatedly in the legal agreement between Whanganui Iwi and the Crown. "Ko au te awa, ko te awa ko au - the health and well-being of the Whanganui River is intrinsically interconnected with the health and well-being of the people" (section 1.8.2). "Whanganui Iwi view the Whanganui River as a living being, Te Awa Tupua; an indivisible whole incorporating its tributaries and all its physical and metaphysical elements from the mountains to the sea" (section 1.2). Similarly, on 20 March 2017, a court in Uttarakhand, India ordered that the Ganga and the Yamuna, and all their tributaries, "are declared as juristic/legal persons/living entities having the status of a legal person with all corresponding rights, duties and liabilities of a living person in order to preserve and conserve river Ganga and Yamuna" (Sharma and Singh 2017:11).
But how can a land or a river talk, express its discontent - or the opposite-its well-being? These no-longer-missing actors are still mute. Stone (2010 [1972]), a legal scholar, has already raised this issue: "It is no answer to say that streams and forests cannot have standing because streams and forests cannot speak" (Stone 2010 [1972]:27). Lawyers can speak for corporations or municipalities, so they can do the same for nature in the name of guardians. Even though they are not currently recognized by law, the deities inhabiting the sacred forests and mountains in Tibet have spoken to the Tibetan people through their shamans for millennia, thus maintaining a topocosmic (i.e., the world order that places humans on the same footing as animals and plants) equilibrium (Studley and Jikmed 2016). In New Zealand, a board appointed by Tûhoe Te Uru Taumatua's trustees and by the ministers will manage the land Te Uwerera, and two river guardians (Te Pou Tupua) appointed by the legislation - one by the Crown, one by the Mâori people living close to the river-will protect and promote the river's status and well-being (Tûtohu Whakatupua: section 2.21). In India, two officers, named persons in loco parentis, are appointed "to promote the health and well being" of the rivers (Sharma and Singh 2017:12).

Does this process once again impose anthropocentric values on nature by deciding what is good for nature and who can speak for nature? If the ventriloquist is not the IPLCs living with and for the river, should it be external specialists in ecology or global policy-makers? Regardless of who speaks for nature, we sustain nature as humans prefer it, but in the Te Urewera and Whanganui river case studies, nature and humans can access the same legal status. In the ontology of the Mâori, humans and nonhumans communicate because one belongs to the other, and reciprocally: "I am the River, and the River is me" (Tûtohu Whakatupua: section 1.1). Studley and Jikmed (2016) provides more insight and examples of how juristic personhood is bestowed upon nonhuman entities and nature. In most contexts, if IPLCs selfdefine human and ecological well-being, and choose relevant indicators via biocultural approaches, we advance toward giving nature a voice.

\section{BIOCULTURAL APPROACHES TO INDICATOR DEVELOPMENT}

Biocultural approaches employ participatory methods for goal setting, identification of locally relevant criteria and indicators of resilience, monitoring, and evaluation, and continued adaptive management (e.g., Tipa and Nelson 2008, Verschuuren 2012, Verschuuren et al. 2014, Wali et al. 2017, Sterling et al. 2017a, McCarter et al. 2018). The process of selecting indicators for human well-being in biocultural landscapes, for example in Bolivia (Escobar 2014) as well as in Ghana (Guri and Verschuuren 2014), shows that many IPLCs recognize a direct link between human well-being and landscape quality. Culture and spirituality form key areas for the selection of community-level indicators. These authors provide examples of indicators for human wellbeing, such as number of sacred sites revitalized and maintained, or cultural festivals celebrated, among many others. The approaches differ significantly in the goal setting, problem identification, and potential solutions in comparison with conventional biodiversity conservation and resource management projects. 
Resulting resilience indicators will also undoubtedly differ depending on the stakeholders, as each ontology relies on different ways of seeing, ordering, ranking, validating, and categorizing elements of a system. For example, 96 varieties of taro (Colocasia esculenta) in a village in Vanuatu hold high cultural heritage value for farmers, as expressed in varieties' names and histories, their exchange potential emphasized by their rarity, and the pride farmers develop when exhibiting their know-how in open water taro pondfields (Caillon and Lanouguère-Bruneau 2005). In contrast, agronomists note that very few clones of taro were introduced in the country, and they worry about the resulting narrow genetic base; most morphological diversity is due to mutations (Caillon et al. 2006). A resilience indicator regarding the number of named varieties in a village will not have the same value depending on the background and interests of each actor. All metrics of resilience reflect the values of the measurers and their ontologies, so it is important to attempt to accommodate diversity (Pascual et al. 2017).

Several groups have already developed culturally grounded indicators, such as the United Nations University (UNU)-United Nations Environment Programme "Learning from the Practitioners" framework, the UNU-Biodiversity Biocultural Indicator Toolkit, and the Melanesian Well-being Indicators, and via the Mauri Model decision-making framework (Morgan 2006, Subramanian and Pisupati 2009, Malvatumauri National Council of Chiefs 2012, Bergamini et al. 2013, UNU-IAS et al. 2014, Sterling et al. 2017a, b). Current methods that expand the breadth of resilience indicators available for decision-making in biocultural approaches include cultural landscape and community asset mapping, multispecies ethnographies, and the development of community well-being indicators for the conservation of biocultural landscapes (Ens 2012, Verschuuren et al. 2014, Pert et al. 2015, Wali et al. 2017, Thach et al. 2017, McCarter et al. 2018).

Sometimes locally important, culturally grounded elements are less tangible and harder to measure than global ones, and we need to identify ways to equitably include them (Nic Eoin and King 2013, Satterfield et al. 2013). These may be locally measured and justified through local ontologies, but they are difficult to translate across scales; e.g., local to national or global (Sterling et al. 2017b, Verschuuren et al. 2014). There are ways, however, to mesh locally derived and internationally generated resilience indicators. For instance, results from cultural landscape mapping could be combined with other spatially explicit indicator compilations, such as the ambitious Biodiversity Indicators Dashboard developed by NatureServe (2012), to better visually capture both cultural and biological elements of a system. However, what remains a challenge is to determine action based on the indicators. By giving recognition to a diversity of ontologies, a new negotiation must occur to determine the indicators that significantly impact directions for collective action. This synthesis across ontologies is still a work in progress in most areas.

Similarly, development of indicators that focus on processes and not just outcomes is an emerging field and a critical part of biocultural approaches to indicator development. Most indicators focus only on the end results of such processes. By just focusing on the outcomes, one risks missing critical elements that contributed to those outcomes. For example, in the Pacific
Northwest of North America, in what is now British Columbia, Canada, humans over thousands of years enriched the terrestrial ecosystems (Trant et al. 2016). First Nations resource use, as evidenced by shell middens in nearshore habitation sites, elevated the soil nutrient composition (especially calcium and phosphorous, which are limiting in these forests otherwise), which led to better growing conditions for the forest as a whole. Through intentional burying of shells from the intertidal zone and use of fire in and near habitation sites, First Nations altered soil chemistry and nutrient availability. In particular, Trant et al. (2016) were able to show the effect of nutrient enrichment on the growth and productivity of the western redcedar (Thuja plicata), a culturally and economically important species. Outcomes-based indicators would focus on the growth and productivity of the cedar and perhaps fail to capture the long-term process of soil nutrient enrichment through the creation of the shell middensthe generations of care that led to their healthy state. In addition, an ecosystem services framework might emphasize the provisioning service that First Nations enjoy in terms of building materials from the forests, while overlooking the critical feedback from First Nations practices that enrich forest ecosystems. Thus, the processes encompassed by relationships between elements in a system need to be measured, in addition to the elements themselves. Indicators for capturing this process might be the number and frequency of additions to shell midden as well as the number, identity, and distribution of people who continue this practice of enriching middens. Better attention to processes and feedbacks could help us sustainably manage resources and increase the well-being of both humans and nature.

Characterization of the connections between humans and their environment, and how they evolve through time, is a product of ontological pluralism, knowledges, sciences, and the different relationships between humans and nature. Working to understand how ontologies and local viewpoints, motivations, and behaviors can improve processes and outcomes helps ensure that people can react or adapt early to a change in a system and subsequently make it more resilient.

\section{CONCLUSION}

We have argued that ecological well-being is an overlooked concept. Better accounting for how human and ecological wellbeing are inextricably related makes conservation approaches more socially just and equitable. We identify some barriers to considering ecological well-being, including the western dichotomy between nature and culture, and a lack of appreciation for how different constructs of nature in different ontologies permeate our values and actions. Other viewpoints on nature and conservation exist: not those that view people and nature as separate, but those in which people are part of nature, where people and nature continuously interact and produce one another. We then show how a more expansive reframing, through the adoption of biocultural approaches, reinforces a "people as part of nature" perspective, can influence the selection and use of new resilience indicators, and can inform conservation practice. In particular, we advocate for the development of indicators that (1) integrate IPLCs' diverse forms of relating to nature, (2) reflect two-way feedbacks between people and their environment (i.e., services to and from ecosystems) (Comberti 2015), (3) include foreground processes, not just outcomes, and (4) define, measure, and monitor both ecological and human well-being. We need 
flexible frameworks and approaches that facilitate synthesis across different metrics, knowledge systems, and ontologies, and that contribute to the creation of a common ground, encompassing human and ecological well-being, on which a joint future for people and nature can be built.

Responses to this article can be read online at: http://www.ecologyandsociety.org/issues/responses. $\mathrm{php} / 9746$

\section{Acknowledgments:}

This paper arose from the session "A brave new world: integrating human well-being in conservation" that was organized by Nicole Gross-Camp and Kelly Biedenweg at the Association for Tropical Biology and Conservation conference in Montpellier, 2016. Part of the material is based upon work, including workshops that convened scientists from different disciplines and with local stakeholders, that was supported by the National Science Foundation under Grants No. EF-1427091 and 1444184. Any opinions, findings, and conclusions or recommendations expressed in this material are those of the author $(s)$ and do not necessarily reflect the views of the National Science Foundation. We thank Christian J. Rivera for help in manuscript preparation. We thank Yildiz Aumeeruddy-Thomas, Joachim Claudet, Nicolas Lescureux, Elise Huchard, Doyle McKey, Julien Renoult, Matthieu Salpeteur, and Gerard Verschoor among others for their contribution of ideas. Most of all, our ideas are brought to life largely by the local peoples with whom we have shared experiences in Vanuatu, the Solomon Islands, Amazonia, Hawai i, Australia, Mongolia, Guatemala, Ghana, and Madagascar.

\section{LITERATURE CITED}

Agrawal, A., and E. Ostrom. 2006. Political science and conservation biology: a dialog of the deaf. Conservation Biology 20:681-682. http://dx.doi.org/10.1111/j.1523-1739.2006.00468.x

Alcorn, J. B. 1993. Indigenous people and conservation. Conservation Biology 7(2):424-426. http://dx.doi.org/10.1046/ j.1523-1739.1993.07020424.X

Altieri, M. A., and L. C. Merrick. 1987. In situ conservation of crop genetic resources through maintenance of traditional farming systems. Economic Botany 41(1):86-96. http://dx.doi. org/10.1007/BF02859354

Aswani, S., and M. Lauer. 2014. Indigenous people's detection of rapid ecological change. Conservation Biology 28:820-828. http:// dx.doi.org/10.1111/cobi.12250

Atran, S., D. L. Medin, and N. O. Ross. 2005. The cultural mind: environmental decision making and cultural modeling within and across populations. Psychological Review 112(4):744-776. http:// dx.doi.org/10.1037/0033-295X.112.4.744

Barry, A., and G. Born, editors. 2013. Interdisciplinarity: reconfigurations of the social and natural sciences. Routledge, Oxford, UK.

Bartlett, C., M. Marshall, and A. Marshall. 2012. Two-eyed seeing and other lessons learned within a co-learning journey of bringing together indigenous and mainstream knowledges and ways of knowing. Journal of Environmental Studies and Sciences 2(4):331340. http://dx.doi.org/10.1007/s13412-012-0086-8

Bates, D. G., and F. Plog. 1990. Human adaptive strategies. Mcgraw-Hill, New York, USA.

Becker, M. 2011. Correa, indigenous movements, and the writing of a new constitution in Ecuador. Latin American Perspectives 38:47-62. http://dx.doi.org/10.1177/0094582X10384209

Béné, C., A. Newsham, and M. Davies. 2013. Making the most of resilience. IDS In Focus Policy Briefings (32).

Bennett, N. J., R. Robin, S. C. Klain, K. M. A. Chan, D. A. Clark, G. Cullman, G. Epstein, M. P. Nelson, R. Stedman, T. L. Teel, et al. 2016. Mainstreaming the social sciences in conservation. Conservation Biology 31:56-66. http://dx.doi.org/10.1111/ cobi. 12788

Bergamini, N., R. Blasiak, P. Eyzaguirre, K. Ichikawa, D. Mijatovic, F. Nakao, and S. M. Subramanian. 2013. Indicators of resilience in socio-ecological production landscapes (SEPLS). UNU-IAS Policy Report. United Nations University Institute of Advanced Studies, Yokohama, Japan. [online] URL: http:// archive.ias.unu.edu/resource centre/Indicators-of-resilience-in-sepls_ev. pdf

Berkes, F. 2008. Sacred ecology: traditional ecological knowledge and resource management. Taylor and Francis, London, UK.

Berkes, F., J. Colding, and C. Folke. 2000. Rediscovery of traditional ecological knowledge as adaptive management. Ecological Applications 10(5):1251-1262. http://dx.doi. org/10.1890/1051-0761(2000)010[1251:ROTEKA]2.0.CO;2

Berlin, B. 1992. Ethnobiological classification: principles of categorization of plants and animals in traditional societies. Princeton University Press, Princeton, New Jersey, USA. http:// dx.doi.org/10.1515/9781400862597

Biedenweg, K., A. Hanein, K. Nelson, K. Stiles, T. Wellman, J. Horowitz, and S. Vynne. 2014. Developing human wellbeing indicators in the Puget Sound: focusing on the watershed scale. Coastal Management 42:374-390. http://dx.doi.org/10.1080/089$\underline{20753.2014 .923136}$

Biedenweg, K., H. Harguth, and K. Stiles. 2017. The science and politics of human well-being: a case study in cocreating indicators for Puget Sound restoration. Ecology and Society 22(3):11. https:// doi.org/10.5751/ES-09424-220311

Blaser, M. 2009. The threat of the Yrmo: the political ontology of a sustainable hunting program. American Anthropologist 111 (1):10-20. http://dx.doi.org/10.1111/j.1548-1433.2009.01073.x

Botsford, L. W., J. C. Castilla, and C. H. Peterson. 1997. The management of fisheries and marine ecosystems. Science 277:509-515. http://dx.doi.org/10.1126/science.277.5325.509

Brosius, J. P. 2006. Common ground between anthropology and conservation biology. Conservation Biology 20:683-685. http://dx. doi.org/10.1111/j.1523-1739.2006.00463.X

Brown, C. H., J. Kolar, B. J. Torrey, T. Truoong-Quang, and P. Volkman. 1976. Some general principles of biological and nonbiological folk classification. American Ethnologist 3(1):73-85. http://dx.doi.org/10.1525/ae.1976.3.1.02a00050 
Burdon, P., editor. 2011. Exploring wild law: the philosophy of earth jurisprudence. Wakefield Press, Adelaide, Australia.

Butchart, S. H. M., M. Walpole, B. Collen, A. van Strien, J. P. W. Scharlemann, R. E. A. Almond, J. E. M. Baillie, B. Bomhard, C. Brown, J. Bruno, et al. 2010. Global biodiversity: indicators of recent declines. Science 328:1164-1168. http://dx.doi.org/10.1126/ science. 1187512

Caillon, S., and V. Lanouguère-Bruneau. 2005. Gestion de l'agrobiodiversité dans un village de Vanua Lava (Vanuatu): stratégies de sélection et enjeux sociaux. Journal de la Société des Océanistes 120-121(1):129-148. http://dx.doi.org/10.4000/jso.451

Caillon, S., J. Quero-García, J.-P. Lescure, and V. Lebot. 2006. Nature of taro (Colocasia esculenta (L.) Schott) genetic diversity prevalent in a Pacific Ocean island, Vanua Lava, Vanuatu. Genetic Resources and Crop Evolution 53(6):1273-1289. http://dx.doi. org/10.1007/s10722-005-3877-X

Cairns, J. 2007. Sustainable co-evolution. International Journal of Sustainable Development \& World Ecology 14:103-108. http://dx. doi.org/10.1080/13504500709469711

Chan, K. M. A., P. Balvanera, K. Benesssaiah, M. Chapman, S. Díaz, E. Gómez-Baggethun, R. Gould, N. Hannahs, K. Jax, S. Klain, et al. 2016. Opinion: Why protect nature? Rethinking values and the environment. Proceedings of the National Academy of Sciences of the United States of America 113:1462-1465. http:// dx.doi.org/10.1073/pnas. 1525002113

Clark, D. A. 2014. Defining and measuring human well-being. Pages 833-855 in B. Freedman, editor. Global environmental change. Springer, Dordrecht, Netherlands. http://dx.doi. org/10.1007/978-94-007-5784-4_66

Comberti, C., T. F. Thornton, V. Wyllie de Echeverri, and T. Patterson. 2015. Ecosystem services or services to ecosystems? Valuing cultivation and reciprocal relationships between humans and ecosystems. Global Environmental Change 34:247-262. http:// dx.doi.org/10.1016/i.gloenvcha.2015.07.007

Conklin, H. C. 1954. The relation of Hanunoo culture to the plant world. Dissertation. Yale University, New Haven, Connecticut, USA.

Costanza, R. 2012. Ecosystem health and ecological engineering. Ecological Engineering 45:24-29. http://dx.doi.org/10.1016/j. ecoleng.2012.03.023

Costanza, R., B. G. Norton, and B. D Haskell. 1992. Ecosystem health: new goals for environmental management. Island Press, Washington, D.C., USA.

Cullinan, C. 2002. Wild law: a manifesto for earth justice. Siber Ink, Cape Town, South Africa.

Daly, E. 2012. The Ecuadorian exemplar: the first ever vindications of constitutional rights of nature. Review of European Community \& International Environmental Law 21:6366. http://dx.doi.org/10.1111/j.1467-9388.2012.00744.x

Descola, P. 1986. La nature domestique: symbolisme et praxis dans l'écologie des Achuar. Edition de la Maison des Sciences de l'Homme, fondation Singer, Paris, France.

Descola, P. 2005. Par-delà nature et culture. Gallimard, Paris, France. http://dx.doi.org/10.3917/deba.114.0086
Drew, J. A. 2005. Use of traditional ecological knowledge in marine conservation. Conservation Biology 19:1286-1293. http:// dx.doi.org/10.1111/j.1523-1739.2005.00158.x

Durkheim, E., and M. Mauss. 1901. De quelques formes primitives de classification: contribution à l'étude des représentations collectives. L'année sociologique 6(1896/18971924/1925):1-72.

Ellen, R. 1998. Indigenous knowledge of the rainforest: perception, extraction and conservation. Pages 87-99 in B. K. Maloney, editor. Human activities and the tropical rainforest: past, present and possible future. Springer Science, Dordrecht, Netherlands. http://dx.doi.org/10.1007/978-94-017-1800-4 5

Emmenegger, S., and A. Tschentscher. 1994. Taking nature's rights seriously: the long way to biocentrism in environmental law. Georgetown International Environmental Law Review 6:552-568.

Ens, E. J. 2012. Monitoring outcomes of environmental service provision in low socio-economic indigenous Australia using innovative CyberTracker Technology. Conservation and Society 10:42-52.

Ens, E., M. L. Scott, Y. M. Rangers, C. Moritz, and R. Pirzl. 2016. Putting indigenous conservation policy into practice delivers biodiversity and cultural benefits. Biodiversity and Conservation 25:2889-2906. http://dx.doi.org/10.1007/s10531-016-1207-6

Escobar, C. 2014. Community well-being in Bolivia: an indigenous perspective. Pages $42-57$ in B. Verschuuren, S. M. Subramanian, and W. Hiemstra, editors. Community well-being in biocultural landscapes: Are we living well? Practical Action Publishing, Bourton on Dunsmore, UK. http://dx.doi. org/10.3362/9781780448374.003

Evans-Pritchard, E. E. 1940. The Nuer: a description of the modes of livelihood and political institutions of a Nilotic people. Oxford University Press, New York, New York, USA.

Friedberg, C. 1990. Le savoir botanique des Bunaq: percevoir et classer dans le Haut Lamaknen (Timor, Indonésie). Editions du Museum National d'Histoire Naturelle, Paris, France.

Friedberg, C. 1992. Représentation, classification: comment l'homme pense ses rapports au milieu naturel. Pages 357-371 in M. Jollivet, editor. Sciences de la nature, sciences de la société. Les passeurs de frontières. CNRS Editions, Paris, France. http://dx. doi.org/10.4000/books.editionsenrs.4204

Gadgil, M., F. Berkes, and C. Folke. 1993. Indigenous knowledge for biodiversity conservation. Ambio 22:151-156.

Gavin, M. C., J. McCarter, A. Mead, F. Berkes, J. R. Stepp, D. Peterson, and R. Tang. 2015. Defining biocultural approaches to conservation. Trends in Ecology \& Evolution 30(3):140-145. http:// dx.doi.org/10.1016/j.tree.2014.12.005

Gillson, L., and K. J. Willis. 2004. 'As Earth's testimonies tell': wilderness conservation in a changing world. Ecology Letters 7:990-998. http://dx.doi.org/10.1111/j.1461-0248.2004.00658.x

Gross-Camp, N. 2017. Tanzania's community forests: their impact on human well-being and persistence in spite of the lack of benefit. Ecology and Society 22(1):37. https://doi.org/10.5751/ ES-09124-220137 
Guri, B. Y., and B. Verschuuren. 2014. Community well-being in Ghana: an African perspective. Pages 78-100 in B. Verschuuren, S. M. Subramanian, and W. Hiemstra, editors. Community wellbeing in biocultural landscapes, are we living well? Practical Action Publishing, Bourton on Dunsmore, UK.

Haraway, D. 2008. When species meet. University of Minnesota Press, Minneapolis., Minnesota, USA.

Heckenberger, M. J., J. C. Russell, J. R. Toney, and M. J. Schmidt. 2007. The legacy of cultural landscapes in the Brazilian Amazon: implications for biodiversity. Philosophical Transactions of the Royal Society B, Biological Sciences 362:197-208. http://dx.doi. org/10.1098/rstb.2006.1979

Hunn, E. 1977. Tzeltal folk zoology: the classification of discontinuities in nature. Academic Press, New York, USA.

Huntington, H. P. 2000. Using traditional ecological knowledge in science: methods and applications. Ecological Applications 10:1270-1274. http://dx.doi.org/10.1890/1051-0761(2000)010[1270: UTEKIS]2.0.CO;2

Ingold, T. 2000. The perception of the environment: essays in livelihood, dwelling and skill. Routledge, London, UK.

Ives, C. D., M. Giusti, J. Fischer, D. J. Abson, K. Klaniecki, C. Dorninger, J. Laudan, S. Barthel, P. Abernethy, B. Martín-López, et al. 2017. Human-nature connection: a multidisciplinary review. Current Opinion in Environmental Sustainability 26-27:106-113. http://dx.doi.org/10.1016/j.cosust.2017.05.005

Jupiter, S. 2017. Culture, kastom and conservation in Melanesia: What happens when worldviews collide? Pacific Conservation Biology 23(2):139-145. http://dx.doi.org/10.1071/PC16031

Kirksey, S. E., and S. Helmreich. 2010. The emergence of multispecies ethnography. Cultural Anthropology 25:545-576. http://dx.doi.org/10.1111/j.1548-1360.2010.01069.x

Kohn, E. 2007. How dogs dream: Amazonian natures and the politics of transspecies engagement. American Ethnologist 34:324. http://dx.doi.org/10.1525/ae.2007.34.1.3

Kuznar, L. A. 2001. Ecological mutualism in Navajo corrals: implications for Navajo environmental perceptions and human/ plant coevolution. Journal of Anthropological Research 57:17-39. http://dx.doi.org/10.1086/jar.57.1.3630796

Lévi-Strauss, C. 1962. La pensée sauvage. Librairie Plon, Paris, France.

Liu, J., and P. Opdam. 2014. Valuing ecosystem services in community-based landscape planning: introducing a wellbeingbased approach. Landscape Ecology 29:1347-1360. http://dx.doi. org/10.1007/s10980-014-0045-8

Maffi, L., and E. Woodley. 2010. Biocultural diversity conservation: a global sourcebook. Earthscan, New York, USA.

Malvatumauri National Council of Chiefs. 2012. Alternative indicators of well-being for Melanesia. Vanuatu Pilot Study Report. Port Villa, Vanuatu.

Marsden, M. 1992. The woven universe: selected writings of Rev. Mâori Marsden. Te Ahukaramu Charles Royal, editor. Estate of Rev Mâori Marsden, Masterton, New Zealand.
Mascia, M. B., J. P. Brosius, T. A. Dobson, B. C. Forbes, L. Horowitz, M. A. McKean, and N. J. Turner. 2003. Conservation and the social sciences. Conservation Biology 17:649-650. http:// dx.doi.org/10.1046/j.1523-1739.2003.01738.x

Massey, D. 1991. A global sense of place. Marxism Today 38:24 29.

Matulis, B. S., and J. R. Moyer. 2016. Beyond inclusive conservation: the value of pluralism, the need for agonism, and the case for social instrumentalism. Conservation Letters 10:279287. http://dx.doi.org/10.1111/conl.12281

McCarter, J., E. J. Sterling, S. D. Jupiter, G. D. Cullman, S. Albert, M. Basi, E. Betley, D. Boseto, E. S. Bulehite, B. Fred, R. Haroni, P. S. Holland, N. Horning, A. Hughes, N. Jino, C. Malone, S. Mauli, B. Pae, R. Papae, F. Rence, O. Revo, E. Taqala, M. Taqu, H. Woltz and C. E. Filardi 2018. Biocultural approaches to developing well-being indicators in Solomon Islands. Ecology and Society 23(1): (in press)

McShane, T. O., P. D. Hirsch, T. C. Trung, A. N. Songorwa, A. Kinzig, B. Monteferri, D. Mutekanga, H. Van Thang, J. L. Dammert, M. Pulgar-Vidal, et al. 2011. Hard choices: making trade-offs between biodiversity conservation and human wellbeing. Biological Conservation 144:966-972. http://dx.doi. org/10.1016/j.biocon.2010.04.038

Mead, H. M. 2003. Tikanga Mâori. Living by Mâori values. Huia Publishers, Wellington, New Zealand.

Menzies, C. R. 2006. Local knowledge and contemporary resource management. University of Nebraska Press, Lincoln, Nebraska, USA.

Moorfield, J. C. 2011. Te Aka Mâori-English, English-Mâori dictionary and index. Third edition. Longman/Pearson, New Zealand.

Morgan, T. K. 2006. Lifting the lid on LID in Aotearoa NZ. NZWWA Conference on Stormwater Management, Aotearoa, New Zealand.

Muller, S. 2012. "Two Ways": bringing indigenous and nonindigenous knowledges together. Pages 59-79 in J. K. Weir, editor. Country, native title and ecology. First edition. Australia National University, Canberra, USA.

NatureServe. 2012. NatureServe Explorer: an online encyclopedia of life. [online] URL: http://dashboard.natureserve.org

Newbold, T., L. N. Hudson, A. P. Arnell, S. Contu, A. De Palma, S. Ferrier, S. L. L. Hill, A. J. Hoskins, I. Lysenko, H. R. P. Phillips, et al. 2016. Has land use pushed terrestrial biodiversity beyond the planetary boundary? A global assessment. Science 353:288291. http://dx.doi.org/10.1126/science.aaf2201

Nic Eoin, L., and R. King. 2013. How to develop intangible heritage: the case of Metolong Dam, Lesotho. World Archaeology 45:653-669. http://dx.doi.org/10.1080/00438243.2013.823885

Ogden, L. A., H. Billy, and T. Kimiko. 2013. Animals, plants, people, and things: a review of multispecies ethnography. Environment and Society 4:5-24. http://dx.doi.org/10.3167/ ares.2013.040102 
Organisation for Economic Co-operation and Development (OECD). 2015. How's life? Measuring well-being. OECD Publishing, Paris, France.

Pascual, U., P. Balvanera, S. Díaz, G. Pataki, E. Roth, M. Stenseke, R. T. Watson, E. Başak Dessane, M. Islar, E. Kelemen, et al. 2017. Valuing nature's contributions to people: the IPBES approach. Current Opinion in Environmental Sustainability 2627:7-16. http://dx.doi.org/10.1016/j.cosust.2016.12.006

Pert, P. L., R. Hill, K. Maclean, A. Dale, P. Rist, J. Schmider, L. Talbot, and L. Tawake. 2015. Mapping cultural ecosystem services with rainforest aboriginal peoples: integrating biocultural diversity, governance and social variation. Ecosystem Services 13:41-56. http://dx.doi.org/10.1016/j.ecoser.2014.10.012

Peterson, R. B., D. Russell, P. West, and J. P. Brosius. 2010. Seeing (and doing) conservation through cultural lenses. Environmental Management 45(1):5-18. http://dx.doi.org/10.1007/s00267-008-9135-1

Pierotti, R., and D. Wildcat. 2000. Traditional ecological knowledge: the third alternative (commentary). Ecological Applications 10:1333-1340. http://dx.doi.org/10.1890/1051-0761 (2000)010[1333:TEKTTA]2.0.CO;2

Pinedo-Vásquez, M., and C. Padoch. 1993. Community and governmental experiences in protecting biodiversity in the lowlands Peruvian Amazon. In C. S. Potter, J. I. Cohen, and D. Janczeweski, editors. Perspectives on biodiversity: case studies in genetic conservation and development. American Association for the Advancement of Science Press, Washington, D.C., USA.

Poe, M. R., J. Donatuto, and T. Satterfield. 2016. "Sense of place": human wellbeing considerations for ecological restoration in Puget Sound. Coastal Management 44:409-426. http://dx.doi. org/10.1080/08920753.2016.1208037

Raudsepp-Hearne, C., G. D. Peterson, M. Tengö, E. M. Bennett, T. Holland, K. Benessaiah, G. K. MacDonald, and L. Pfeifer. 2010. Untangling the environmentalist's paradox: Why is human well-being increasing as ecosystem services degrade? BioScience 60:576-589. http://dx.doi.org/10.1525/bio.2010.60.8.4

Roué, M. 2014. Chapitre 7: La théorie anthropologique au secours de la complexité. Comment penser et étudier les relations sociétésnatures. Page 182 in R. Chernokian and S. Robert, editors. Les interactions hommes-milieux. Vol. Indisciplines. Editions Quae éditions, Paris, France.

Sandbrook, C., W. M. Adams, B. Büscher, and B. Vira. 2013. Social research and biodiversity conservation. Conservation Biology 27(6):1487-1490. http://dx.doi.org/10.1111/cobi.12141

Satterfield, T., R. Gregory, S. Klain, M. Roberts, and K. M. Chan. 2013. Culture, intangibles and metrics in environmental management. Journal of Environmental Management 117:103114. http://dx.doi.org/10.1016/j.jenvman.2012.11.033

Schaeffer, D. J., E. E. Herricks, and H. W. Kerster. 1988. Ecosystem health: I. Measuring ecosystem health. Environmental Management 12:445-455. http://dx.doi.org/10.1007/BF01873258

Sharma, R. J., and A. J. Singh. 2017. In the High Court of Uttarakhand at Nainital. Writ Petition (PIL) No. 126 of 2014, March 20.
Spiegel, J. M., M. Bonet, A. Yassi, E. Molina, M. Concepcion, and P. Mast. 2001. Developing ecosystem health indicators in centro Habana: a community-based approach. Ecosystem Health 7:15-26. http://dx.doi.org/10.1046/j.1526-0992.2001.007001015. $\underline{x}$

Starik, M. 1995. Should trees have managerial standing? Toward stakeholder status for non-human nature. Journal of Business Ethics 14(3):207-217. http://dx.doi.org/10.1007/BF00881435

Sterling, E. J., C. Filardi, J. Newell, S. Albert, D. Alvira, N. Bergamini, E. Betley, M. Blair, D. Boseto, K. Burrows, et al. 2017b. Biocultural approaches to well-being and sustainability indicators across scales. Nature Ecology \& Evolution. http:// doi:10.1038/s41559-017-0349-6

Sterling, E. J., A. Sigouin, C. E. Filardi, J. Newell, D. Alvira, N. Bergamini, K. Burrows, S. Caillon, J. Claudet, G. Cullman, et al. $2017 a$. Culturally grounded indicators of resilience in socialecological systems. Environment and Society: Advances in Research 8:63-95. http://dx.doi.org/10.3167/ares.2017.080104

Stone, C. D. 2010 [1972]. Should trees have standing? Law, morality, and the environment. Third edition. Oxford University Press, Oxford, UK.

Strathern, M. 1980. No nature, no culture: the Hagen case. Page 227 in C. P. MacCormack and M. Strathern, editors. Nature, culture and gender. Cambridge University Press, London, UK.

Studley, J., and A. Jikmed. 2016. Creating new discursive terrain for the custodians of Tibetan spiritscacpes of north west Yunnan. Pages 259-273 in B. Verschuuren and N. Furuta, editors. Asian sacred natural sites: philosophy and practice in protected areas and conservation. Routledge, London, U.K.

Subramanian, S. M., and B. Pisupati. 2009. Learning from the practitioners: benefit sharing perspectives from enterprising communities. United Nations Environment Programme, Nairobi, and United Nations University Institute for the Advanced Study of Sustainability, Tokyo.

Tengö, M., E. S. Brondizio, T. Elmqvist, P. Malmer, and M. Spierenburg. 2014. Connecting diverse knowledge systems for enhanced ecosystem governance: the multiple evidence base approach. Ambio 43:579-591. http://dx.doi.org/10.1007/ $\underline{\text { s13280-014-0501-3 }}$

Thạch, H. M., M. D. Le, N. B. Vũ, A. Panariello, G. Sethi, E. J. Sterling, and M. E. Blair. 2017. Slow loris trade in Vietnam: exploring diverse knowledges and values. Folia Primatologica, in press.

Tipa, G., and K. Nelson. 2008. Introducing cultural opportunities: a framework for incorporating cultural perspectives in contemporary resource management. Journal of Environmental Policy \& Planning 10(4):313-337. http://dx.doi. org/10.1080/15239080802529472

Tiwari, B. K., S. K. Barik, and R. S. Tripathi. 1998. Biodiversity value, status, and strategies for conservation of sacred groves of Meghalaya, India. Ecosystem Health 4:20-32. http://dx.doi. org/10.1046/j.1526-0992.1998.00068.x

Trant, A. J., W. Nijland, K. M. Hoffman, D. L. Mathews, D. McLaren, T. A. Nelson, and B. M. Starzomski. 2016. Intertidal 
resource use over millennia enhances forest productivity. Nature Communications 7:12491. http://dx.doi.org/10.1038/ncomms12491

Tsing, A. L. 2015. The mushroom at the end of the world: on the possibility of life in capitalist ruins. Princeton University Press, Princeton, New Jersey, USA. http://dx.doi.org/10.1515/9781400873548

Tzoulas, K., K. Korpela, S. Venn, V. Yli-Pelkonen, A. Kaźmierczak, J. Niemela, and P. James. 2007. Promoting ecosystem and human health in urban areas using green infrastructure: a literature review. Landscape and Urban Planning 81:167-178. http://dx.doi.org/10.1016/j.landurbplan.2007.02.001

United Nations Development Programme (UNDP). 2016. Human development report 2016. Human development for everyone.

United Nations University Institute for the Advanced Study of Sustainability (UNU-IAS), Bioversity International, IGES, and United Nations Development Programme (UNDP). 2014. Toolkit for the indicators of resilience in socio-ecological production landscapes and seascapes (SEPLS). [online] URL: http://www. bioversityinternational.org/uploads/tx news/Toolkit for the indicators of iesilience in socio-ecological_production_landscapes and seascapes 1844.pdf

van Oudenhoven, F. J. W., D. Mijatović, and P. B. Eyzaguirre. 2011. Social-ecological indicators of resilience in agrarian and natural landscapes. Management of Environmental Quality: An International Journal 22(2):154-173. http://dx.doi. org/10.1108/14777831111113356

Verschuuren, B. 2012. Integrating biocultural values in nature conservation: perceptions of culturally significant sites and species in adaptive management. Pages 231-246 in G. Pungetti, G. Oviedo, and D. Hooke, editors. Sacred sites and species: guardians of biocultural diversity. Cambridge University Press, Cambridge, UK. http://dx.doi.org/10.1017/CBO9781139030717.023

Verschuuren, B. 2016. Re-awakening the power of place: ancient philosophy and practice with relevance for protected areas and conservation in Asia. Pages 1-14 in B. Verschuuren and N. Furuta, editors. Asian sacred natural sites: philosophy and practice in protected areas and conservation. Routledge, London, UK.

Verschuuren, B., S. M. Subramanian, and W. Hiemstra, editors. 2014. Community well-being in biocultural landscapes: Are we living well? Practical Action Publishing, Amazon Digital Services LLC. http://dx.doi.org/10.3362/9781780448374

Verschuuren, B., M. Zylstra, and B. Yunupingu. 2015. Mixing waters: a cross-cultural approach to developing guidelines for fishers and boaters in the Dhimurru protected area, Australia. PARKS: International Journal on Protected Areas and Conservation 21(March). http://dx.doi.org/10.2305/IUCN.CH.2014. PARKS-21-1BV.en

Vitousek, P. M., H. A. Mooney, J. Lubchenco, and J. M. Melillo. 1997. Human domination of Earth's ecosystems. Science 277:494 499. http://dx.doi.org/10.1126/science.277.5325.494

Viveiros de Castro, E. 1992. From the enemy-s point of view: humanity and divinity in an Amazonian society. University of Chicago Press, Chicago, Illinois, USA.
Viveiros de Castro, E. 1998. Cosmological deixis and Amerindian perspectivism. Journal of the Royal Anthropological Institute 4:469-488. http://dx.doi.org/10.2307/3034157

Wali, A., D. Alvira, P. S. Tallman, A. Ravikumar, and M. O. Macedo. 2017. A new approach to conservation: using community empowerment for sustainable well-being. Ecology and Society 22(4):6. https://doi.org/10.5751/ES-09598-220406

Walley, C. J. 2002. 'They scorn us because we are uneducated': knowledge and power in a Tanzanian marine park. Ethnography 3:265-298. http://dx.doi.org/10.1177/146613802401092751

West, P. 2005. Translation, value, and space: theorizing an ethnographic and engaged environmental anthropology. American Anthropologist 107:632-642. http://dx.doi.org/10.1525/ aa.2005.107.4.632

West, P. 2006. Conservation is our government now: the politics of ecology in Papua New Guinea. Duke University Press Books, Durham, North Carolina, USA. http://dx.doi.org/10.1215/9780$\underline{822388067}$

West, P. 2016. An anthropology for 'the assemblage of the now'. Anthropological Forum 26: 438-445. http://dx.doi. org/10.1080/00664677.2016.1246089

Zylstra, M. J., A. T. Knight, K. J. Esler, and L. L. L. Le Grange. 2014. Connectedness as a core conservation concern: an interdisciplinary review of theory and a call for practice. Springer Science Reviews 2(1-2):119-143. http://dx.doi.org/10.1007/ $\underline{\mathrm{s} 40362-014-0021-3}$ 